\title{
Un programa de archiserafines encriptados en la capilla de los arcedianos de la catedral de Baeza
}

\author{
Pablo Jesús Lorite Cruz ${ }^{1}$
}

\begin{abstract}
Resumen: Este breve artículo trata sobre la representación iconológica de los siete generales de Dios (arcángeles de serafines) mediante el uso complementario de los siete pecados capitales y las siete virtudes que luchan contra los mismos. Dicho programa se encuentra en la capilla de San Miguel de la catedral de Baeza.

Palabras Clave: Arcángeles, virtudes, pecados capitales, catedral de Baeza, siglo XVI, iconografía.
\end{abstract}

Abstract: This little article talks about iconologic representation of the God's seven generals (archangels seraphim). This happens with complementary use of the seven deadly sins and the seven virtues; they fight with those. This artistic work is in the Saint Michael's chapel of the Baeza's cathedral.

Keywords: Archangels, virtues, deadly sins, Baeza's cathedral, Sixteenth century, iconography.

El inicio de este artículo nos introduce en un término difícil de la naturaleza de los ángeles, los archiserafines o los arcángeles de serafines, aquellos seis más dos generales de los ejércitos de Dios, los que se encuentran por encima de los serafines (primer coro de la primera jerarquía); del mismo modo aquellos que vencen a los siete pecados capitales. ${ }^{2}$ No es el fundamento de este texto entrar en el debate de los ángeles que tanto difiere de teólogos del siglo XV como puede ser el caso de Francesc de Eiximenis en su Llibre dels angels al tratado de Blasco de Lanuza por ejemplo. Para entender la obra que vamos a analizar hay que basarse en la creencia que primó la existencia de los archiserafines.

Nuestro estudio se basa en el programa iconológico existente en la capilla de San Miguel de la catedral de Baeza, la más conocida del templo metropolitano junto a la capilla dorada, por atribuirse ambas a la gramática renacentista de Andrés de Vandelvira y todos aquellos arquitectos que en el siglo XVI trabajaron en los conjuntos monumentales de Úbeda y Baeza declarados Patrimonio Mundial por la UNESCO.

Es la primera de la nave del evangelio, paralela a la ubicación antigua del coro gótico, por tanto, una de las existentes en la zona más antigua de la catedral (no hay que olvidar que hasta el siglo XVIII las capillas existían desde el crucero al presbiterio, quedando la mayor parte del templo desde este punto con pequeños grupos de dos capillitas en cada arco lateral que no estaban al descubierto y que se vienen a definir perfectamente en la visita realizada en el siglo XVII). ${ }^{3}$

\footnotetext{
${ }^{1}$. Doctor en historia del arte por la Universidad de Jaén y experto universitario en gestión del patrimonio por la Universidad Internacional de Andalucía. pablochechu@ gmail.com.

${ }^{2}$ Blasco de Lanuza, F. de. (O.S.B.). 1652. Patrocinio de Ángeles y combate de demonios... Es una ilustración de los beneficios que hacen los ángeles de la guarda a los hombres: 486. Real Monasterio de San Juan de la Peña.

${ }^{3}$ Cfr. Lorite Cruz, P. J. 2011."Las capillas de la catedral de Baeza según la visita realizada en 1625." Claseshistoria. Agosto 2011: 216: 1-28. Vélez-Málaga: IES Juan de la Cierva.
} 
Tradicionalmente, es conocida como la capilla de los arcedianos, puesto que fue fundada por Diego de Luca y Francisco de Herrera (ambos con esta dignidad eclesiástica en Jaén). Data de 1560 para la nueva obra de la catedral, ${ }^{4}$ se afirma que contribuyó Ginés Martínez de Aranda junto a Vandelvira en su ejecución. ${ }^{5}$ De hecho, la complejidad del programa iconográfico, carente de precedentes (al menos, que nosotros conozcamos), se debe a una persona de extremada cultura que daría órdenes precisas a los ejecutores de lo que debían de realizar en aquella capilla, independientemente del magisterio artístico insertado por el genial arquitecto.

Es una capilla de poco fondo, igual que todas las existentes en la catedral (donde el muro grueso primó en la nave con una importante reminiscencia medieval), y de pequeño tamaño. Está presidida por un retablo barroco, donde existe un lienzo de San Miguel, atribuido a Bernardo Germán Lorente. Este cuadro es gemelo del existente en la capilla de los Ángeles de la catedral de Jaén, ${ }^{6}$ muy posiblemente el autor realizara primero el lienzo de la catedral baezana y posteriormente el de la giennense, ya que en esta segunda versión añade un león en el infierno y más adelante veremos la importancia que tiene dicho animal en la capilla que estudiamos.

Las intenciones tanto de Francisco de Herrera como las de su sobrino Diego Lucas es el enterramiento en esta capilla, y el de sus descendientes. La renta que deja para la fábrica de la misma muestra el poderío de ambos, pues en principio entrega como limosna a la fábrica de la catedral 40 ducados, mientras que para su capilla mantendrá una dotación basada en un beneficio de 10000 ducados, diez años después de que la obra esté terminada ${ }^{7}$ (cantidad muy considerable).

En la actualidad la fábrica nos muestra una policromía absoluta, formada por un arco de medio punto; en el intradós de éste aparece una serie de relieves de virtudes encasetonadas. Cada virtud presenta dos cartelas, una sobre la cabeza, que la identifica, y otra sobre los pies, que indica el vicio que vence. Ya Santo Tomás de Aquino indicaría la complementariedad existente entre los siete pecados capitales y las virtudes que los vencen, ${ }^{8}$ algo que no debió de ser desconocido a los teólogos que pensaron en esta capilla que dejan patente conocer los escritos del citado Padre de la Iglesia.

El arco de medio punto es completado en su totalidad por el lienzo y la decoración dorada del marco, quedando de esta forma las virtudes rodeándole. La lección primordial, al tratarse de siete, la tenemos en la cuarta, puesto que ocupa la clave del arco y es la Humildad, virtud principal del arcángel vencedor de la soberbia de Satanás; hace alusión directa al general celeste (a San Miguel, al mismo que está dedicada la capilla), al igual que honra con su presencia en el armario de las tres llaves de esta catedral, obra contemporánea a ésta, hoy conservada en el archivo histórico municipal de la ciudad donde el archiestratega celeste lleva en su escudo el blasón municipal de la ciudad de Baeza. ${ }^{9}$

La presencia de esta virtud, al ser tan distante en el tiempo el cuadro de San Miguel hace pensar en la existencia de otro San Miguel en la capilla antes de que se realizara el actual. Es tan sólo una teoría, que no podemos confirmar. Sin embargo, la unión entre la Humildad y San Miguel es totalmente clara (Qvis ut Devs, ¿quién cómo

\footnotetext{
${ }_{4}^{4}$ Archivo Catedral de Baeza (en adelante Acb). Libro primero de fundaciones de capellanías. Fol. 285 r.

${ }^{5}$ AAVV. 2000. Guía de Úbeda y Baeza: 214. Torredonjimeno: Universidad de Jaén.

6 Aragón Moriana, A. 1991. "Noticias en torno a Bernardo Lorente Germán." Senda de los Huertos. Revista cultural de la provincia de Jaén. 22: 47-50. Jaén: Asociación amigos de San Antón.

${ }^{7}$ Acb. Libro primero de fundaciones de capellanías. Fol. $285 \mathrm{r}$.

${ }^{8}$ Aquino, Tomás de. Siglo XIII (reed. 1988) Suma Teológica: Prima Secundae. Cuestión 71. Madrid: BAC.

${ }^{9}$ Cfr. Lorite Cruz, P. J. 2011. "El armario de las tres llaves de la catedral de Baeza, un interesante discurso de virtudes del siglo XVI." Claseshistoria: septiembre de 2011, N. ${ }^{\circ}$ 221: 1-16. Vélez-Málaga: IES Juan de la Cierva.
} 
Dios?, significado de la palabra Miguel que representa la humildad del que obtuvo el poder al adorar a los hombres por orden del Altísimo y enfrentarse al otro gran archiserafín Lucifer que desde aquel momento pasaría a ser el diablo). De hecho, creemos que nunca hubo otro lienzo alusivo al general celeste en la capilla. Al menos, en el siglo XVII ésta no estaba presidida por este supuesto, sino por una imagen de la Virgen del Pópulo, según la visita llevada a cabo el 3 de octubre de $1625 .{ }^{10}$

Las virtudes representadas desde la Humildad hacia la izquierda son la Templanza, Paciencia y Diligencia, mientras que en el lado derecho se conservan la Caridad, Largueza y Castidad. Esta selección de virtudes no responde a la común, donde suelen aparecer las cuatro cardinales y las tres teologales, pues tan sólo tenemos a una teologal (la Caridad) y a otra cardinal (la Templanza).

Curioso es que el número sea siete, como siete son los vicios que llevan al hombre a los pecados capitales, que combaten los siete arcángeles, ${ }^{11}$ de los cuales es príncipe San Miguel; por ello la Humildad queda arriba presidiendo la capilla. De hecho, la presencia de las virtudes es una manera más teológica de representar a los siete arcángeles. Aquí es donde indicamos el título de este artículo, los archiserafines no aparecen, sino que están encriptados y hay que descifrarlos iconológicamente.

Observando otras obras de Vandelvira en las que hizo uso de virtudes y dioses olímpicos en el intradós, es común que siempre su presencia se base en una utilidad clara, perfectamente legible desde una dimensión iconológica. Por ejemplo, en la Sacra Capilla de El Salvador de Úbeda los dioses simbolizan los astros conocidos hasta el momento, los cuatro elementos de la tierra y el amor de Dios por haber realizado esta creación (cada dios que suple a un cuerpo celeste se encuentra acompañado por un putto que indica de qué clase de cuerpo se trata); en la capilla dorada de la catedral de Baeza responden a una dimensión claramente escatológica en recuerdo a Pedro Muniz, deán de la catedral de Lima en donde la representación de los Reyes Magos vienen a indicar el psicopompo del deán en su propia tumba y al mismo tiempo el patronazgo de estos sobre la ciudad de Lima. ${ }^{12}$

¿Quién compone estos programas iconológicos de tanta complejidad? ¿A qué mentalidad culta del momento se deben? Evidentemente, a Andrés de Vandelvira no. En el Salvador se barajan dos nombres: en primer lugar, el deán Ortega, hombre muy culto para su época (aunque no llevo a cabo o no están documentados programas tan complejos en su palacio ubetense o en su capilla de enterramiento de la parroquia de San Nicolás en Úbeda, sí en la reja de la misma, pero no a estos niveles), y, en segundo lugar, Pérez de Ayala, que en aquellos momentos estaba por la zona y es posible que al igual que entrara en contacto con Francisco de los Cobos lo pudiera hacer con estos canónigos baezanos, que de igual modo creemos que debían de tener un elevado grado cultural.

Todo el intradós de la capilla de San Miguel se corresponde en el siguiente cuadro:

\footnotetext{
${ }^{10}$ Acb. Libro de visitas de capellanías... Fol. $191 \mathrm{r}$.

${ }^{11}$ Brancasi, C. (O.F.M.). 1646. De angelis: 452-453. Napoli = Nápoles: Ex Regia Typographia Egydij Longhi. Evidentemente es una idea recogida a posteriori por el napolitano teólogo franciscano. Concretamente el mismo aclara que son ellos siete quienes vencen a los siete pecados capitales con las siete virtudes. Presentamos un pequeño fragmento de dicho texto: (...) Angelos eos intelligunt, quibus specialis custodia demandata sit pro hominibus ad expunanda septe pecata mortalia (...).

${ }^{12}$ Cfr. Lorite Cruz, P. J. 2010. "El sepulcro de Pedro Muniz de Molina, deán de la catedral de Lima. Los reyes magos en la catedral de Baeza, un icono procedente de Lima." Nonnullus: N. ${ }^{\circ}$ 6: 90-94. Badajoz: Plataforma digital Nonnullus.
} 


\begin{tabular}{|l|l|l|}
\hline Virtud & $\begin{array}{l}\text { Vicio y animal que lo } \\
\text { representa }\end{array}$ & Arcángel \\
\hline Humildad & Soberbia: León & Miguel \\
\hline Templanza & Gula: Cerdo & Saeltiel \\
\hline Paciencia & Ira: Oso & Uriel \\
\hline Diligencia & Pereza: Lirón & Balaquiel \\
\hline Caridad & Envidia: Perro & Jehudiel \\
\hline Largueza & Avaricia: Pavo Real & Rafael \\
\hline Castidad & Lujuria: Cabra & Gabriel \\
\hline
\end{tabular}

En primer lugar, vamos a detenernos en el análisis del intradós y seguidamente haremos referencia a otra serie de detalles que forman parte de la capilla y que responden a un todo iconológico. Para el estudio de las virtudes vamos a basarnos sobre todo en la investigación exhaustiva realizado por el profesor León Coloma sobre las mismas, ${ }^{13}$ teniendo en cuenta que nuestra aportación es hacia los archiserafines que nunca se han tenido en cuenta en el estudio de la capilla, de hecho en la última publicación llevada a cabo por Cuadros Trujillo (posterior a la lectura de nuestra tesis) tampoco se tiene en cuenta; en este sentido consideramos en tener que volver a replantear todo el programa.

-Humildad: Cada virtud aparece dentro de un óvalo, inserto en cada uno de los siete casetones, mostrando en la parte superior dos pequeños angelitos, que recostados sobre el marco circular sostienen la cartela en donde se identifica a la virtud. Concretamente, el epígrafe de ésta es VMILDAD.

Son imágenes de rostro genérico, prácticamente idéntico en todas ellas, a pesar de encontrarse en posiciones diferentes. Destacables son también sus peinados, muy densos y redondeados, así como sus gruesas túnicas y mantos. La Humildad aparece vestida con túnica de tonalidades rojas y manto azulado, ${ }^{14}$ con una actitud clásica como todas las demás. Junta las manos en señal de oración, a la vez que pisa tres leones. Ripa posteriormente a la época en que se realiza esta capilla, describirá esta representación de la Humildad en su compendio, indicando que debe de tener bajo sus pies una víbora medio muerta (símbolo del odio y la envidia, lógicamente haciendo alusión a la primera metamorfosis del demonio para tentar a Eva), ${ }^{15}$ enroscada en un espejo roto (significa el amor propio) y un león herido (alude a la soberbia). ${ }^{16}$

Existen dos detalles: el primero es que tan sólo se representa al león, pues el verdadero interés es la figuración del vicio de la soberbia, no la de los demás que puede combatir la Humildad, y el segundo es que todas las virtudes tienen el vicio representado por tres animales repetidos. El número tres es muy coherente en esta ocasión, pues, visto desde el lado del Bien, tres son las personas de la Santísima Trinidad, como tres son los arcángeles aceptados por la Iglesia Católica.

Sin embargo, es más interesante observar la trilogía desde la perspectiva del pecado, pues, además de que Satanás tenga dos ayudantes principales, se considera

\footnotetext{
${ }^{13}$ León Coloma, M. A. 1990. "Un programa iconográfico de vicios y virtudes en la catedral de Baeza." Ephialte. Lecturas de historia del arte: $\mathrm{N}^{\circ}$ 2: 312-315. Vitoria: Universidad del País Vasco. Instituto de estudios iconográficos de Vitoria-Gasteiz.

${ }^{14}$ Colores afines a la representación de las imágenes gloriosas de la Virgen hasta la definición en el siglo XVII de la iconografía de la Purísima Concepción cuando autores como Bartolomé Esteban Murillo, Gregorio Fernández, Mateo Sedano, Juan Valdés Leal, Alonso Cano,... primen el celeste y blanco frente al rojo.

${ }^{15}$ Ge. 3, 1-24.

${ }^{16}$ Ripa, C. (reed. 2002) Iconología: tomo I: 499-500. Madrid: Ediciones Akal.
} 
que todo mortal cuando peca de un vicio lo hace por tres veces; con la mente, con el corazón y con el cuerpo. ${ }^{17}$ A todo esto hemos de añadir que el león se puede considerar como un animal soberbio, puesto que es el más grande de los felinos y, por tanto, considerado como el rey de la selva.

Junto a esta idea de la fiera soberbia, hay que destacar un relato apócrifo que apoya que el Niño Jesús fue adorado por una manada de leones, que con tan sólo ocho años fue capaz de doblegar la soberbia de estas fieras: Había una madriguera en donde una leona criaba a sus cachorros. Esta era la causa por la que nadie transitaba seguro por aquellos parajes. Llegó, pues, Jesús al lugar, a sabiendas de que en aquella caverna había parido la leona a sus crías. A vista de todos entró en la cueva. Los leoncitos que le vieron, corrieron a Él y le adoraron. Jesús se sentó en medio de la gruta, y ellos correteaban en torno suyo, acariciándole y jugueteando, mientras que los leones más viejos estaban retirados cabizbajos, haciéndole fiestas con la cola. ${ }^{18}$

El antagonismo entre la Humildad y la Soberbia es tratado por Dante en la Divina Comedia. Concretamente, el escritor humanista se encuentra con las almas en pena caídas por la soberbia en un pantano de fétido olor, desde el cual reciben los insultos por parte del único barquero que cruza (Flegias): ¡Cuántos se tienen allá arriba por grandes reyes y serán arrojados a esta ciénaga, sin dejar en pos de sí más que horribles desprecios! $!^{19}$

Las manos unidas de la virtud pisando una fiera puede evocar la iconografía de la Inmaculada Concepción, que comenzará a adquirir forma en el siglo siguiente. Sin embargo, nosotros no creemos que la virtud esté evocando un tema mariano, sino que se trata de una abstracción que quiere representar al mismo San Miguel, mediante la virtud que le otorgó el poder que su antagonista ansiaba, de igual modo que los tres leones simbolizan al maligno, que es vencido por la misma.

Descartamos el tema de la Purísima por otra punto lógico, en el episcopado de Alonso Suárez de la Fuente del Sauce ${ }^{20}$ el maestro Bartolomé está trabajando como rejero para la catedral de Baeza y en el diseño de la reja que cerraría el coro antiguo (posteriormente el moderno de 1635) no aparece ninguna prefiguración de la misma, pero sí en rejas de su autoría existentes en la diócesis de Baeza-Jaén, como la de la capilla de la Yedra de la colegiata de Úbeda o la de la Santa Capilla de la Purísima Concepción de la parroquia de San Andrés en Jaén, en ambas representa el abrazo de San Joaquín y Santa Ana en la puerta de Jerusalén. ${ }^{21}$

En resumen, hemos de entender todo este programa iconográfico como una compleja representación de la lucha contra el pecado, evocada mediante los siete espíritus primarios que asisten a Dios, como los seres más perfectos de la creación, sin necesidad de estar éstos presentes en identificación física, sino más bien psíquica mediante las virtudes que los sustituyen.

\footnotetext{
${ }^{17}$ Sea ilustrativo de esta idea que en la administración del sacramento de la Extremaunción al moribundo se le perdonan los pecados cometidos con la mente, el corazón y las manos. Per istam Sanctam Unctionem, et suam piissimam misericordiam, indulgeat tibi Dominus quidquid per visum deliquisti. Amen. Per istam Sanctam Unctionem (...) per auditum deliquisti (...) per odoratum deliquisti (...) per gustum et locutionem deliquisti (...), ... Ratti, A. (Pío XI) 1935. Rituale Romanum:78-79. Ciudad del Vaticano: Editio Juxta Typicam Vaticanam.

18 Pseudo Mateo. Cap. XXXV En De Santos Otero, Aurelio. 2003. Los Evangelios Apócrifos. Madrid: Biblioteca de Autores cristianos.

${ }^{19}$ Dante Alighieri (reed. 1987). La Divina Comedia: 25. Madrid: Editorial Mediterráneo.

${ }^{20}$ Obispo de Baeza-Jaén desde 1500 a 1522.

${ }^{21}$ Domínguez Cubero, J. 1989. La rejería de Jaén en el siglo XVI: 110-112. Jaén: Diputación provincial y Lorite Cruz, P.J. 2010. "Las iconografías de Santa Ana como precedentes de las Inmaculada Concepción, el beso en la puerta de Jerusalén y la Sagrada Parentela. El triunfo de la mujer en la estirpe de Cristo. II Congreso virtual sobre historia de las mujeres: Comunicación N. ${ }^{\circ}$ 5: 1-13. Jaén: Asociación Amigos del Archivo Histórico Diocesano.
} 
Por ello en la clave se encuentra la Humildad, puesto que San Miguel es el principal de ellos. De hecho, aunque no existiera el lienzo del siglo XVIII que nos presenta al arcángel en la batalla del principio de los tiempos, la capilla seguiría teniendo el mismo significado.

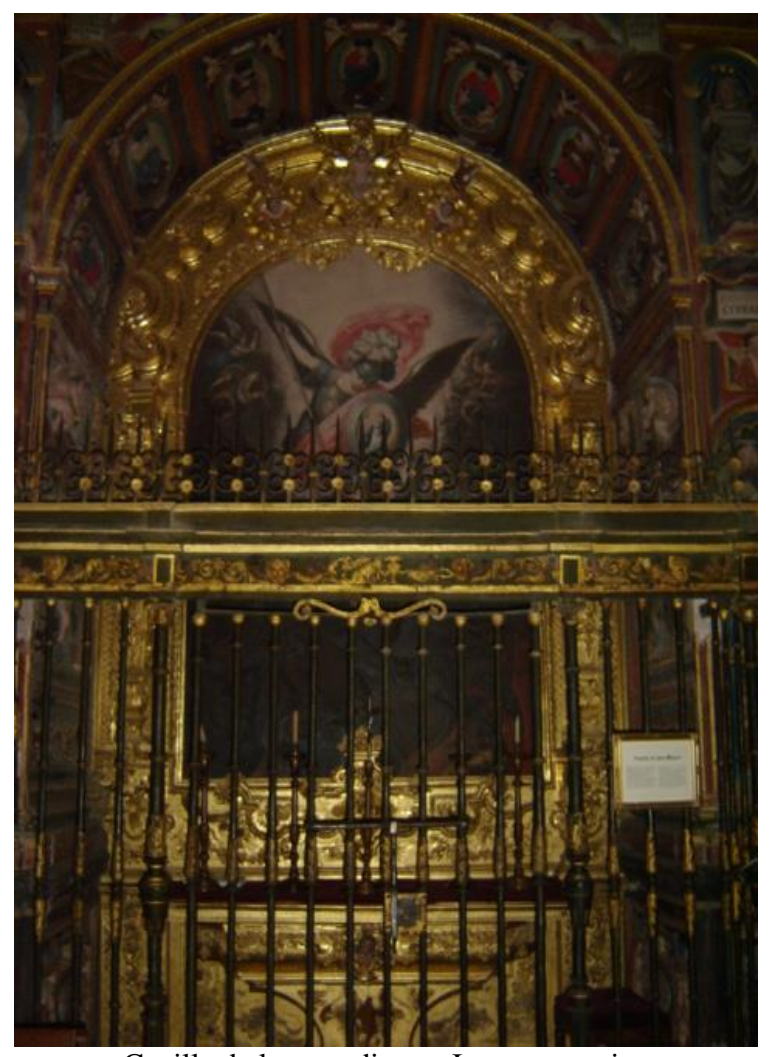

\section{-Templanza:}

Capilla de los arcedianos. Imagen propia.

Siguiendo hacia el lado izquierdo desde la Humildad, en sentido descendente, nos encontramos con la Templanza. Con iguales características en el rostro y peinado que la anterior, viste túnica y un voluminoso manto. Como atributos iconográficos tiene una jarra que vuelca para verter un determinado líquido en un vaso, con el cuidado de que éste no caiga al suelo. Normalmente, se suele identificar con vino, evocando la costumbre grecorromana de mezclarlo con agua para depurarlo por su fortaleza (gesto que se sigue realizando con otra lectura más rica en la consagración católica del vino en Sangre de Cristo, de aquí el uso de las vinajeras; independientemente de que la lectura sea mucho mayor al representar en este caso a los presentes en la cena que caen a la sangre redentora de Jesús). De hecho el vino en los festejos no siempre era bueno y si existía una partida de gran calidad se reservaba para un determinado momento, queda muy claro en el milagro de Cristo en las bodas de Caná cuando convierte el agua en el mejor vino. ${ }^{22}$

Ripa recogerá con posterioridad que la Templanza es una especie de equilibrada moderación, guiada y determinada por un certero raciocinio. El hecho de imaginarla rellenando con un líquido un recipiente desde otro tiene el significado de que lo mismo ocurre en efecto con la moderación, que une en uno solo, cual dos distintos líquidos, dos distintos extremos. ${ }^{23}$

\footnotetext{
22 Jn. 2, 1-12.

${ }^{23}$ Ripa, C. (reed. 2002): Tomo 2: 353.
} 
La identificación se realiza con el arcángel Saeltiel (Plegaria de Dios), el más parecido a los querubines por permanecer más tiempo en profunda adoración a Dios y en cierto modo el más distante a los hombres de los siete, por tener un comportamiento más parecido al de los serafines. Su carácter más ascético conecta con el justo reparto de los bienes, basado en cubrir las necesidades básicas. Por tanto, es todo lo contrario a la Gula.

Este pecado capital no puede ser mejor representado que con la efigie del cerdo, pues se trata de un animal tragón y ansioso, incapaz de dominar sus placeres y deseos. Será la Historia Natural de Plinio la que afirme que las hembras muchas veces devoran a sus propias crías, costumbre explicada por Eliano y basada en la misma voracidad de este animal. ${ }^{24}$

Es tan popularizada la glotonería del cerdo que desde la mitología hasta las diferentes religiones tienen algo que decir de él. Por ejemplo, Homero en La Odisea cuenta cómo muchos de los compañeros de Ulises son convertidos en cerdos por la maga Circe. ${ }^{25}$

Existen muchas representaciones de los pecados capitales en donde éstos son reconocidos por el animal. Por ejemplo, Hans Burkmair realizó una serie de grabados sobre vicios propios de animales, muy similares a los presentados en estos relieves "vandelvirianos". La gula con el cerdo, el león para la soberbia, el sapo para la envidia (en Baeza aflorará el perro), el pavo real junto a la avaricia, la lujuria carece en esta ocasión de animal (los arcedianos disfrutarían en su capilla de la presencia de la cabra) y el burro para la pereza (en Baeza el lirón).

El comparar a estas virtudes con Burkmair se debe a que este grabador alemán es coetáneo al momento en que se realiza la capilla, lo que nos lleva a pensar que este criterio representativo de ciertos animales como portadores de los pecados capitales debía de ser bastante conocido entre las mentalidades cultas de la época a nivel internacional. El hecho que ya no es tan común es esa lectura iconológica a favor de los arcángeles como archiserafines.

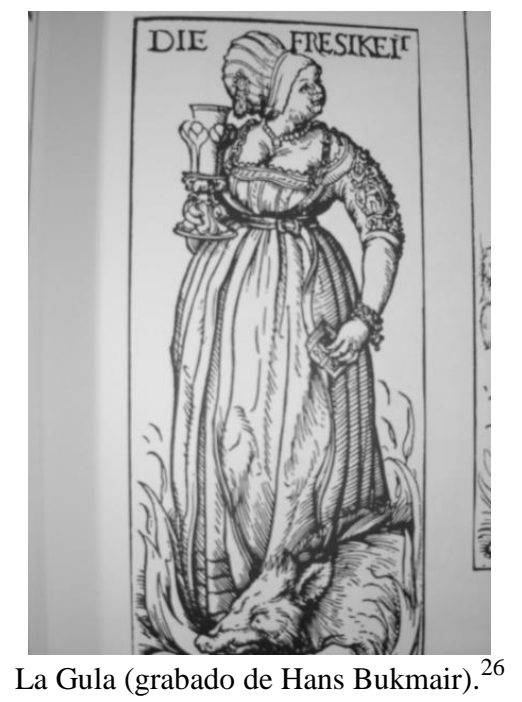

A todo esto podemos añadir que Ripa asocia también el cerdo a las representaciones de la Avidez, pues mientras devora una bellota mira la rama de

\footnotetext{
${ }^{24}$ León Coloma, M. A. 1990: 313.

${ }^{25}$ Homero, (reed. 1982). La Odisea: Canto X. Madrid: Gredos.

${ }^{26}$ Barscht, A. 1989. The Ilustrated: 11: 61-64. Nueva York: Abaris Books.
} 
encima para no perder de vista otra; además, es un animal incapaz de parar de engullir mientras tenga comida. ${ }^{27}$ También se le figura junto a la Crápula (efectos de la Gula), por ser un animal que come en el fango sin alzar la mirada.

Aparece en el Desprecio de la Virtud pisoteando rosas, simbolizando, según los antiguos egipcios, una vida llena de costumbres desordenadas (al mismo tiempo es un insulto a la Rosa Mística -uno de los parangones de la Virgen María en las letanías lauretanas, a la que evidentemente se le contesta ora pro nobis-. También, junto al Ocio, pues la vida del ocioso viene a ser como la de un cerdo por su vileza y flojedad. ${ }^{28}$

No solo queda el cerdo en cierto modo despreciado en la religión católica (donde sólo se considera bendito al lado de San Antonio Abad), ${ }^{29}$ sino que los islamistas consideran que es un animal que siempre mira al suelo por encontrarse lleno de demonios introducidos en las piaras por Cristo, ${ }^{30}$ para ellos un profeta admirable, no el Hijo de Dios. Queda muy claro en algunas aleyas que no se puede comer la carne de este animal. ${ }^{31}$

Volvemos a encontrarnos ante una abstracción del propio Saeltiel, que no daba lugar a los problemas que conllevaba representar un arcángel que no era muy bien aceptado por diversas teorías teológicas. Por ejemplo, Interián de Ayala es quien en siglos posteriores nos indica que la pérdida de estos otros cuatro, a pesar de ser nombrados por importantes teólogos, se debe sobre todo al siglo VIII, momento en el cual el papa San Zacarías ${ }^{32}$ en el concilio romano del año 745 reconoció tan solo a los tres primeros por miedo a una serie de nombres dados por un hereje llamado Adalberto, que nombraba una serie que se podían considerar como espíritus malignos (Ragúel, Jubuel, Adimis, Jubuas, Sabaoth, Simihel,...). ${ }^{33}$

\section{-Paciencia:}

La siguiente virtud es la Paciencia. Su iconografía es un tanto extraña, pues aparece con el torso desnudo frente al grosor de su túnica y las manos unidas junto al pecho (como si se encontraran atadas por las muñecas); el rostro cabizbajo evoca cierta actitud de dolor, más psíquico que físico, quizá producido por alguna clase de humillación. Será Ripa quien recogerá que a veces puede aparecer descalza, pisando ramas espinosas. Podemos observar que, en realidad, se encuentra representada como si hubiera recibido alguna clase de insulto y pacientemente tratara de soportarlo (todo lo contrario a la reacción que experimentaría una persona llena de Ira).

León Coloma piensa que esta obra es heredera de la iconografía del Ecce Homo (recordemos que se trata del pasaje en que Jesús maniatado, coronado de espinas y con un manto púrpura, es presentado por Poncio Pilatos al pueblo y la multitud se mofa de él, ante lo que Cristo humildemente agacha la cabeza y aguanta la mofa, a sabiendas que era el mismo Dios). ${ }^{34}$

Efectivamente la Paciencia lleva a la gloria, las escrituras cristianas lo muestran en numerables ocasiones con Cristo, pensemos como en toda su pasión fue paciente esperando su glorioso final, incluso hay textos evangélicos que manifiestan

\footnotetext{
${ }^{27}$ León Coloma, M. A. 1990: 314.

${ }^{28}$ Ripa, C. (reed. 2002): Tomo I: 239, 240, 274. Tomo II: 143.

${ }^{29}$ Dicho santo es representado con una cerda a los pies, pues según la tradición por ayuda del canonizado a ésta le siguió y sirvió durante toda su vida como si de un perro se tratase.

${ }^{30}$ Mt. 8, 28-34.

${ }^{31}$ Mahoma, (reed. 2007). El Corán: Sura II, 172. Madrid: Edimat.

${ }^{32}$ Sumo Pontífice Romano desde 741 al 752.

${ }^{33}$ Interián de Ayala, Fr. J. 1782. El pintor christiano, y erudito, ó Tratado de los errores que suelen cometerse freqüentemente en pintar, y esculpir las Imágenes Sagradas. Libro II. Cap. VII: 147-148. Madrid: Traducido al castellano por Don Luis de Durán y Bastéro. Joaquín Ibarra, Madrid 1782. Edición facsímil, Alicante, 2001.

${ }^{34}$ Jn. 19, 4.
} 
cómo es paciente hasta para que sus propios apóstoles entiendan a qué había venido (el caso claro lo tenemos cuando en la Última Cena increpa a San Felipe al preguntarle si todavía no lo conocían, por pedirle el apóstol sensato que les mostrara al Padre). ${ }^{35}$

En esta ocasión sería la representación de San Uriel. Éste nos presenta una lectura antagónica de los atributos de la Ira, pues él es el fuego de Dios (fuego ardiente de amor), que como vigilante paciente guarda las puertas del cielo con la espada (puso delante del jardín del Edén los querubines y la espada de la llama flameante para guardar el camino del árbol de la vida). ${ }^{36}$

\section{-Ira:}

Respecto a la Ira, representada mediante el oso, se trata como un animal tradicionalmente muy feroz. De igual modo, Ripa lo añade en su propia descripción artística de la Ira. Ciertamente, el oso es un animal muy traicionero y peligroso, pues puede atacar sin motivo a quien se cruce en su camino; además, su ataque es furioso basado en zarpazos.

Es una fiera muy propia de la Edad Media, siendo presentado en las poblaciones por algunos saltimbanquis que lo habían conseguido domesticar; también se utilizaban en diversiones de nobles; por ejemplo, el condestable de Castilla Miguel Lucas Iranzo una vez abandonada la corte de Enrique $\mathrm{IV}^{37}$ y establecido en Jaén con su feudo propio, los soltaba en días festivos para ser cazados. ${ }^{38}$

Ripa recogerá que la Ira puede ser evocada con fuego y humo, pues una antorcha encendida viene a ser como el corazón del hombre enfurecido que de continuo arde y se consume. Del mismo modo, la Ira también porta una espada, puesta que es vengativa y con gran rapidez hace uso de la violencia física. ${ }^{39}$ Muchas veces la ira se manifiesta incluso de manera física, pues los iracundos se arañan en muchas ocasiones por impotencia.

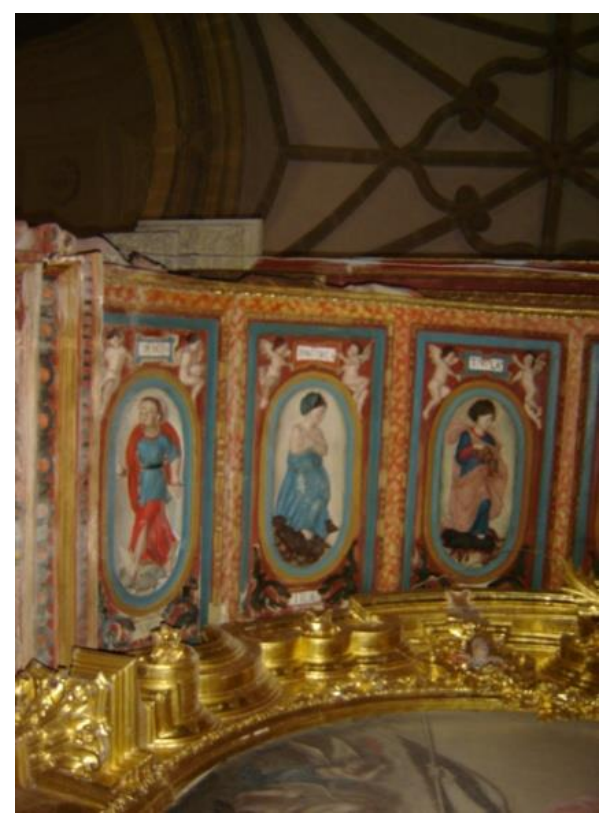

Diligencia, Paciencia y Templanza pisando sus respectivos vicios. Imagen propia.

\footnotetext{
35 Jn. 14, 8-11.

${ }^{36}$ Ge. 3, 24.

${ }^{37}$ Rey de Castilla desde 1454 a 1474.

${ }^{38}$ Cuevas Mata, J. ; Del Arco Moya, Ju. y Del Arco Moya, Jo. (reed.2001) Relación de los hechos del muy magnífico e más virtuoso señor, el señor Don Miguel Lucas, muy digno Condestable de Castilla: Año 1564. Jaén: Universidad de Jaén.

${ }^{39}$ Ripa, C. (reed. 2002): Tomo I: 538.
} 


\section{-Diligencia:}

La última virtud de este lado es la Diligencia, personificada como una mujer presurosa con alas en los pies (atributo común de Mercurio ${ }^{40}$ pero también de la Rapidez y la Fama). Pensemos que el principal icono del dios es el caduceo que a la vez que en las botas, también porta alas ese bastón que tiene dos serpientes enroscadas en símbolo de Prudencia, mientras que las alas son la Diligencia, dos virtudes muy importantes en el comercio, por tanto que el caduceo aparezca en monedas del Alto Imperio, por ejemplo en denarios de Vespasiano. ${ }^{41}$

Con los ojos muy abiertos y en actitud más dinámica que la de los demás relieves se apoya sobre tres lirones. El lirón es un animal identificado con la Pereza, puesto que, según Ripa recoge de Marcial, la mayor parte del tiempo está como perdido en lo profundo del sueño y privado de todo sentimiento y de toda actividad, manteniéndose siempre como en noche perpetua. ${ }^{42}$

También, suele acompañar a la representación de la Hora Octava, por ser ésta la hora en que los hombres aprecian el sueño más profundo, así como volverá a aparecer en La Cuarta Parte de la Noche $^{43}$ (estas fracciones horarias hay que entenderlas en el siglo XVI, pues en la actualidad son variables). Es posible que estas ideas se tuvieran en cuenta en la realización del programa pese a ser anterior.

La conexión es con San Balaquiel (Bendición de Dios), ya que una persona bendecida por Dios es diligente, santifica su vida diaria, no puede estar quieta, siempre tiene que hacer algo por el bien de los demás. Por ello esta unión con el general de Dios que es normalmente representado como el que reparte o bendice la tierra con flores indicando como Dios bendice al hombre diariamente con la propia naturaleza, el regalo gratuito de Dios para el disfrute de los hombres.

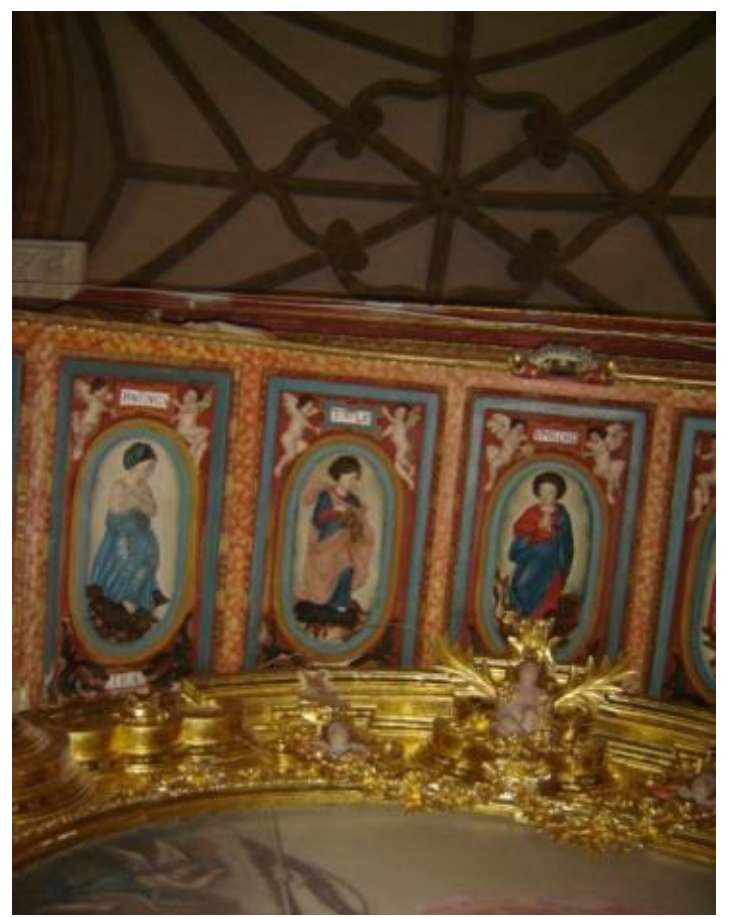

Paciencia, Templanza y Humildad pisando a sus respectivos vicios. Imagen propia.

\footnotetext{
${ }^{40}$ Hay que resaltar que Andrés de Vandelvira representa a Mercurio con alas en los pies en uno de los casetones del intradós de la puerta principal de la Sacra Capilla Funeraria de El Salvador de Úbeda.

${ }^{41}$ Cayón, J. 1995. Compendio de las monedas del Imperio Romano: tomo 2: 1376. Madrid: Editado por el autor.

${ }^{42}$ León Coloma, M. A. 1990: 313.

${ }^{43}$ Ripa, C. (reed. 2002): Tomo I: 497. Tomo II: 135.
} 


\section{-Caridad:}

En el lado contrario la primera virtud de la que podemos disfrutar es la única teologal presente en todo el programa: la Caridad. Está pensada con su iconografía más común, nacida de los mismos tondos y monedas romanas en que aparecen matronas amamantando a niños, tradición representativa que se afianzará en los siglos XIII y XIV ${ }^{44}$. Produce cierta evocación medieval por ese manto rojo, que abierto acoge bajo él a los niños, Nos puede recordar a las famosas Vírgenes de la Merced, que con sus enormes mantos amparan a los marineros.

La presencia de los tres perros es una asociación que viene de Plinio y que afirma que dicho animal, por su instinto, conoce una hierba que sana de la mordedura de serpiente, pero que tan sólo se proporciona a escondidas para no ser descubierto por los hombres. ${ }^{45}$ Además, el perro tiene un carácter parecido al adulador, pues halaga para pedir comida y después es posible que muerda a aquel que lo alimenta. ${ }^{46}$ Es algo experimentable incluso al contrario, un perro por muy fiero que sea se amansa delante de quien le ofrece comida, incluso en algunos mitos griegos se hace referencia a que incluso a veces el Cancerbero se volvía dócil ante la comida.

Si definimos la envidia como el querer poseer los bienes del prójimo, ${ }^{47}$ es muy lógico que el espíritu que combata este pecado sea Jehudiel (Remuneración de Dios) por su función de justiciero. A este general celeste se le representa como el más temido, pues en una mano presenta una corona para quien haya seguido el buen camino y en la otra un látigo, para el pecador, el mismo elemento castigador que Cristo utilizó para expulsar a los mercaderes del templo ${ }^{48}$ y que tan bien fue representado por El Greco. No olvidemos que la Caridad cristiana se divide en los que se llaman las siete obras de misericordia corporales obligatorias de todo creyente de la susodicha religión: "Dar de comer al hambriento, dar de beber al sediento, vestir al desnudo, visitar a los enfermos, asistir al preso, dar posada al caminante y sepultar a los muertos." Órdenes que vienen del propio Jesús. ${ }^{49}$

\section{-Largueza:}

En principio, nos puede parecer una mujer austera, pero si nos fijamos tiene en sus manos una cajita de la cual va lanzando monedas (atributo del que habla Cicerón), la limosna que, según la Iglesia, hay que dar hasta que duela (quinto mandamiento de la Santa Madre Iglesia). ${ }^{50}$ Es contraria al pecado del que lo quiere todo para él.

Dante cuenta que el castigo que observó destinado para los avariciosos en el infierno es el de arrojarse piedras a la vez de lamentarse por atesorar riquezas, ${ }^{51}$ lo contrario a la Largueza con las monedas. El pecado es identificado mediante el pavo real. El doctor León nos indica de nuevo que es un animal normalmente más utilizado para el Orgullo, pero que por su belleza se identifica con los ricos, con el glamur.

Recordemos que, según la mitología, en un principio el pavo real no tenía tanta belleza y se parecía más bien a un pavo normal, pero será la diosa del matrimonio Hera (Juno) quien, tras perder a su fiel servidor Argos, una vez que Mercurio le da muerte por espiar y vigilar las escapadas de Júpiter (expresado el momento por grandes maestros como Velázquez o Rubens), le adorne su cola con los cien ojos que pertenecían a Argos.

\footnotetext{
${ }^{44}$ León Coloma, M. A. 1990: 314.

${ }^{45}$ Ibídem.

${ }^{46}$ Ripa, C. (reed. 2002): Tomo I: 68.

${ }^{47}$ No codiciarás los bienes ajenos. Décimo mandamiento de la ley de Dios. De. 5, 21.

48 Jn. 2, 15.

${ }^{49}$ Mt. 25, 31-46

${ }^{50}$ Ayudar a la Santa Madre Iglesia en sus necesidades.

${ }^{51}$ Dante Alighieri (reed. 1987): Canto séptimo del infierno: 23.
} 
De hecho, un pavo real muestra su riqueza cuando quiere, abriendo el abanico de su cola. Ciertamente, es un animal exótico para los ricos (la riqueza siempre se consigue por avaricia). Del mismo modo, es un ave chillona que entra dentro de los delirios de grandeza pedantes en los que caen los sobrantes de caprichos. ${ }^{52}$ También se considera al pavo como un ave empalagosa e insoportable. Por ello dirá Ripa que se pinta junto a la adolescencia por el "pavo" que tienen los hombres en esta etapa de su vida donde la psicología habla de la fábula personal. Nosce te ipsum dirá Sócrates ("conócete a ti mismo"). Pero, el problema es que muchas veces nuestro amor propio no nos lo permite, por ello que ésta sea representada con un pavo, pues el amor propio en el fondo nos hace egocéntricos. También la arrogancia toma a este animal como significado de la soberbia ignorante ${ }^{53}$ que en algunas ocasiones lleva incluso al desarrollo del cretino digno de lástima.

La relación es con San Rafael, pues la medicina o médico de Dios está considerado como el que con largueza ayuda a los fieles. De hecho, su actitud protectora frente a Tobías, totalmente desinteresada, rompe todas las cuestiones de avaricia. San Rafael es todo lo contrario, no se conforma con dar los bienes materiales que intentan atesorar los avariciosos, sino que entrega su propia persona, su propia condición de archiserafín al servicio de los hombres. Del mismo modo por el relato de Tobías, San Rafael es un general viajero y de hecho así se presenta en la principal de sus iconografías frente a la confinación de Asmodeo en el desierto que también suele ser común; y evoca que nada puede llevarse el hombre, pues tras el último viaje todo queda en la tierra y como indicará en el siglo XVII Pedro Calderón de la Barca en su gran teatro del mundo, peregrinamos desde la cuna a la tumba, por ello que a lo largo de la obra se repita (en realidad se canta) en muchas ocasiones por parte del personaje de la Ley de Gracia: "Obrar bien que Dios es Dios." 54

\section{-Castidad:}

Quizás, una de las más fáciles de identificar sea la Castidad, sobre todo por pisar cabras (símbolo absoluto de la lujuria). Aparece vestida con túnica y manto negro sobre la cabeza, indicando un carácter un tanto inaccesible. Ripa refiere que puede ir tocada y en cierto modo engalanada como una vestal, aludiendo casi a una condición de viudedad (parecido a la imagen que tenemos). También se resaltará el color blanco de su túnica, por su propia pureza; en esta ocasión viste de azul celeste, color con el mismo significado dentro de España.

Respecto a la palma, puede tener varios significados. Ripa, concretamente, alude a que puede llevar una rama de cinámono (planta aromática y preciosa), que simboliza el preciosismo absoluto de la virtud de la Castidad. El problema es que, en realidad, no sabemos distinguir si la virtud porta una rama de dicho vegetal o simplemente es una palma. El profesor León Coloma, por su parte, especifica que puede significar un instrumento de azote para la mortificación. ${ }^{55}$

Nosotros nos vamos a atrever a indicar otra posible solución, que dejamos claro que tan solo la utilizamos como hipótesis. Teniendo en cuenta que nos encontramos ante una clara representación simbólica de los arcángeles y que antes de la existencia del cuadro de San Miguel en el centro de la capilla existía una Virgen, podemos pensar que esta palma es heredera de la que la Señora recibió de manos del general celeste y entregó a San Juan para sus funerales. En cierto modo, este icono milagroso tenía una función profiláctica hasta la Asunción de María (especulemos que representaciones tan antiguas de este pasaje como el declarado Patrimonio Mundial

\footnotetext{
52 León Coloma, M. A. 1990: 315.

${ }^{53}$ Ripa, C. (reed. 2002): Tomo I: 65, 90, 112.

${ }^{54}$ Calderón de la Barca, P. (reed. 2007). El gran teatro del mundo: 790. Barcelona: Linkgua Ediciones.

${ }^{55}$ León Coloma, M. A. 1990: 315.
} 
intangible del Misterio de Elche gira en torno a esta palma que se reparte al final de la representación entre los asistentes). Si existe una personalidad casta es la Bienaventurada Virgen María como queda claro en el pasaje de la Anunciación ${ }^{56}$ y todo lo ocurrido posteriormente contado en los Evangelios y en los Apócrifos.

Respecto a las cabras, mucho podemos decir de este animal loco, utilizado por la tradición iconográfica para metamorfosear al demonio (el mismo Goya la utilizó en sus pinturas negras, concretamente en el aquelarre). Hecho lógico, puesto que uno de los pecados capitales más extendidos es éste (no cometerás actos impuros dice el sexto mandamiento). De hecho, desde la antigüedad ha sido un animal asociado a seres mitológicos de cierta brutalidad, como puede ser el caso de Pan, o a seres eminentemente sexuales, como es el caso de los sátiros, que de cintura para abajo tienen forma de cabra.

Existe una tradición que apoya la lubricidad de las cabras y, en especial, del macho cabrío. Ya Plutarco aludía a su incapacidad de continencia; Horacio, a su lascivia; Claudio Eliano, a la barbaridad de que pueden llegar a copular con mujeres. San Isidoro, por su parte, se fija en sus ojos de pupilas atravesadas, indicando su mirada sucia. Por último, Alciato la utiliza en tres emblemas de la lujuria. ${ }^{57}$

Todo esto ha hecho que la cabra herede uno de los peores conceptos dentro del reino animal, hasta tal punto que también es identificada con la infidelidad matrimonial; dentro de la jerga española está completamente estandarizado que quien metafóricamente porta las mismas defensas que el macho cabrío ha sufrido esta terrible experiencia de deshonra (resuelta en siglos pasados mediante duelo, pensemos tan solo en $\mathrm{La}$ Regenta: "que la reparación lo sea, además terrible y rápida", palabras que el literato pone en la boca del deshonrado Víctor de Quintanar), ${ }^{58}$ por lo que uno de los peores insultos realizados en castellano alude al citado animal. No sólo queda ahí, en las zonas rurales existe un mote maldito, soez y considerablemente grosero para las familias donde un miembro masculino ha sido descubierto por la vecindad copulando con una cabra.

El arcángel, al que representa este relieve, es San Gabriel. No puede ser otro, teniendo en cuenta que el ejemplo más puro de castidad y obediencia es el texto evangélico al que aludíamos antes de la Anunciación. Por ello en la mayoría de los San Gabriel al presentarse a la Virgen casos porta en sus manos una rama de azucenas (otro símbolo de la pureza), pensemos en representaciones como las que llevaron a cabo Tiziano, El Greco, Fray Filippo Lippi,...

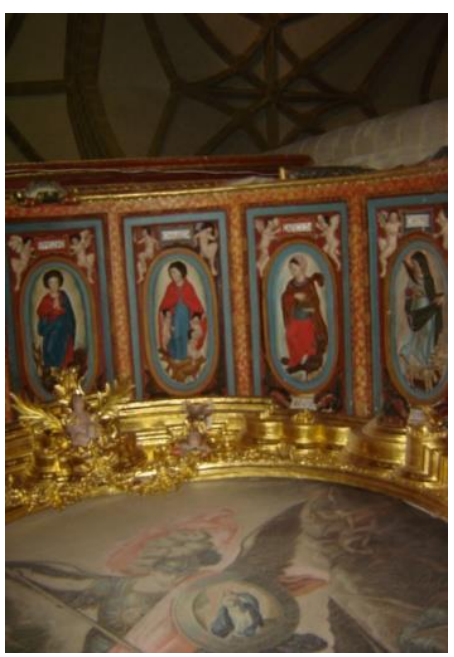

Humildad, Caridad, Largueza y Lujuria pisando sus respectivos vicios. Imagen propia.

\footnotetext{
${ }^{56}$ Lc. 1, 26-38.

${ }^{57}$ León Coloma, M. A. 1990: 315.

${ }^{58}$ Alas Clarín, L. (reed. 2005). La Regenta: tomo 2: 792. Madrid: Edimat Libros.
} 
Una vez observadas todas las virtudes y sus respectivos vicios, hemos de afirmar que existe una lectura aún más profunda que concurría en la época, por la cual podemos entender todo este conjunto de vicios como la propia representación del diablo, al cual sólo la figura de San Miguel es capaz de vencer. Tenemos en esta capilla manifestado el fin del mundo, sin la necesidad de encontrarse presente ni el general celeste ni el maligno. Por ello en el siglo XVII la capilla no tenía un San Miguel; no lo necesitaba, estaba presente. Quizá la figura de la Virgen que presidía el altar era el programa completo, una vez que veamos el resto de relieves de la capilla.

Basamos esta lectura en un grabado de Durero, que debió entender bien la idea de que la conjunción de todos los pecados capitales daban lugar a la figura de Satanás. Así lo representa en una obra ambigua de la batalla celeste, donde San Miguel desciende desde el cielo para con un candado encadenar al diablo. La idea principal la tenemos en el maligno, representado como monstruo de siete cabezas, donde el artista deja claro que cada una de ellas es una representación de cada uno de los siete pecados capitales teniendo la forma del animal que los simboliza. Es evidente que nos encontramos ante una representación de la Mujer vestida de Sol (María) ante el dragón de siete cabezas del cual nos habla el Apocalipsis. ${ }^{59}$

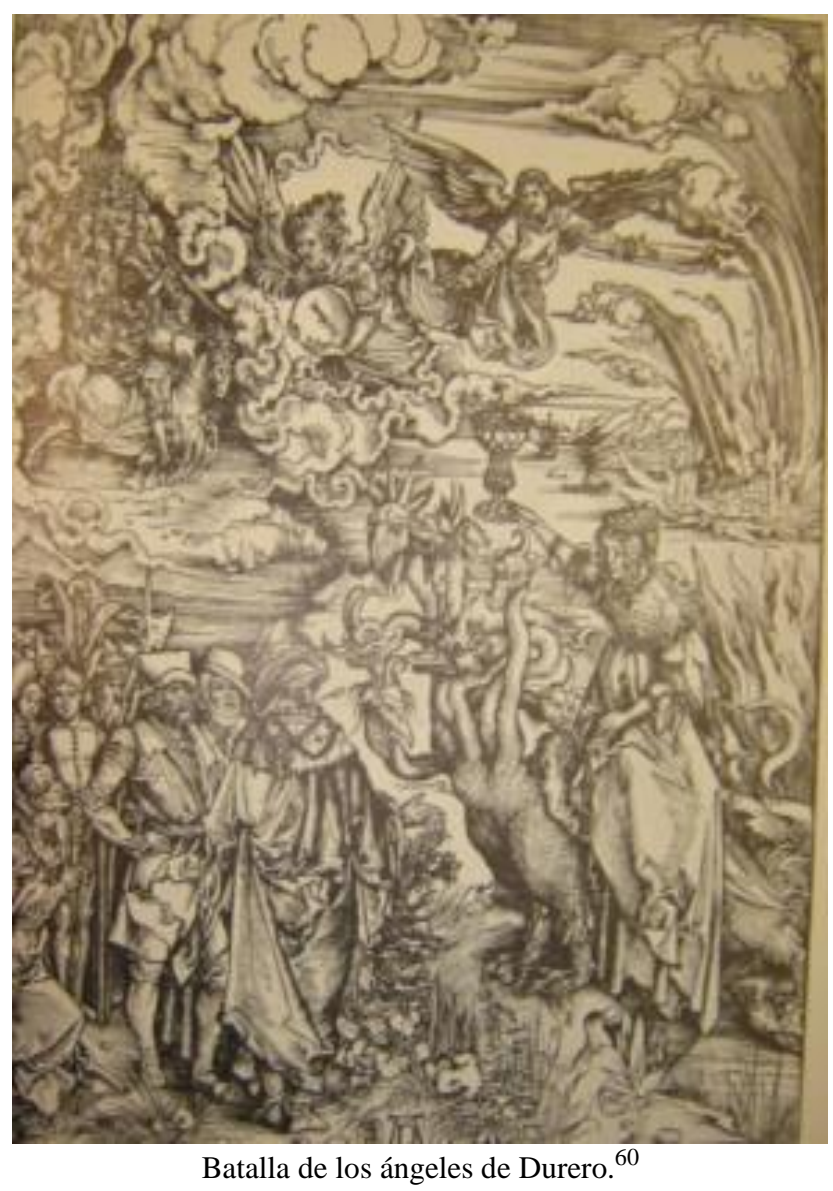

Tras las virtudes, a cada lado del arco, se van a insertar dos escenas de Jesús, que son un ejemplo de la misma idea de Dios-Hombre; concretamente, las tentaciones de Jesús para que pecara y la limpieza absoluta mediante su Bautismo, en símbolo más de apoteosis que de perdón, pues Jesús no necesitaba ser bautizado.

\footnotetext{
${ }^{59}$ Ap. $12,3$.

${ }^{60}$ AAVV.1 976. Symboles de la Renaissance: Fig. 2. París: Presse de 1’Ecole Normale Supérieure. París.
} 
Ambos relieves indican al fiel cómo el hombre es tentado, pero ese hombre, al ser hijo de Dios y formar parte de su comunidad mediante el bautismo, es capaz de vencer a los siete vicios capitales y todos sus complementarios. El de la derecha presenta las tentaciones, utilizando en primer plano la tentación de las piedras, en la cual el demonio vestido de ermitaño portando un rosario (atributo mariano anacrónico) en actitud de engaño ofrece a Jesús una piedra para que Éste la convierta en pan y rompa su ayuno de cuarenta días.

Cristo, vestido también de una manera ascética (con túnica oscura), conversa con total tranquilidad con el demonio negándose a su ofrecimiento (No sólo de pan vive el hombre, sino de toda palabra que sale de la boca de Dios). En segundo plano, las otras dos tentaciones; en el ángulo izquierdo, el ofrecimiento de toda la Tierra si se postra ante Belcebú. En esta ocasión el demonio ya no adopta la forma de ermitaño, sino de ángel enrojecido. Y, por último, en el lado derecho, la subida al templo y tentación por parte del mismo de que se arroje, para ser cogido en el aire por los ángeles, pues al ser el mismo Hijo de Dios nada le habría de pasar.

Entre la virtud y este grabado existe un espacio en el que dos putto sostienen una cartela latina que alude a lo representado abajo: DVCTVS / EST IESVS IN/ DESERTVM /ASPIRITV / Mat. 4. (Luego el Espíritu llevó a Jesús al desierto, para ser tentado por el diablo).

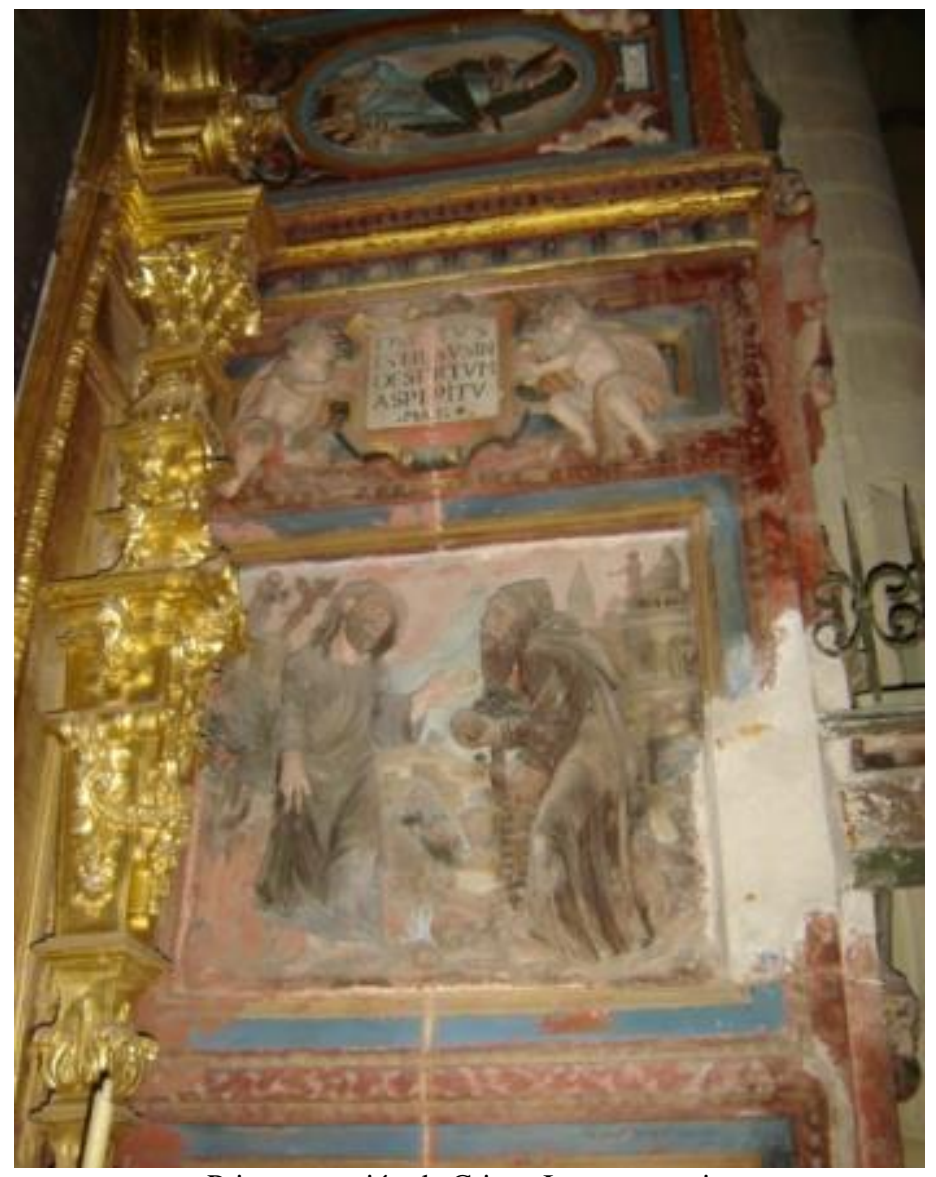

Primera tención de Cristo. Imagen propia.

En el lado contrario, el Bautismo está resuelto con la tradición iconográfica más frecuente. Jesús se ha quitado la túnica que ha dejado en un árbol y sobre las aguas del Jordán, con las manos unidas en oración recibe el bautismo mediante la 
concha de vieira utilizada por San Juan Bautista, que responde a sus atributos más comunes: la piel de camello con la cual viste y los largos cabellos y barba.

Dentro de un decorado boscoso, Cristo tapa el sol, lo que le permite una considerable idea de luminosidad, a la vez que el Espíritu Santo (en forma de paloma) sobrevuela su cabeza indicando la grandeza del evento. La cartela superior recoge las palabras de Dios Padre dadas a los hombres a favor de Jesús: HIC EST FI / LIVS MEVS/ DILECTVS / Matei 3 (Este es mi Hijo -"el amado"-, escuchadle).

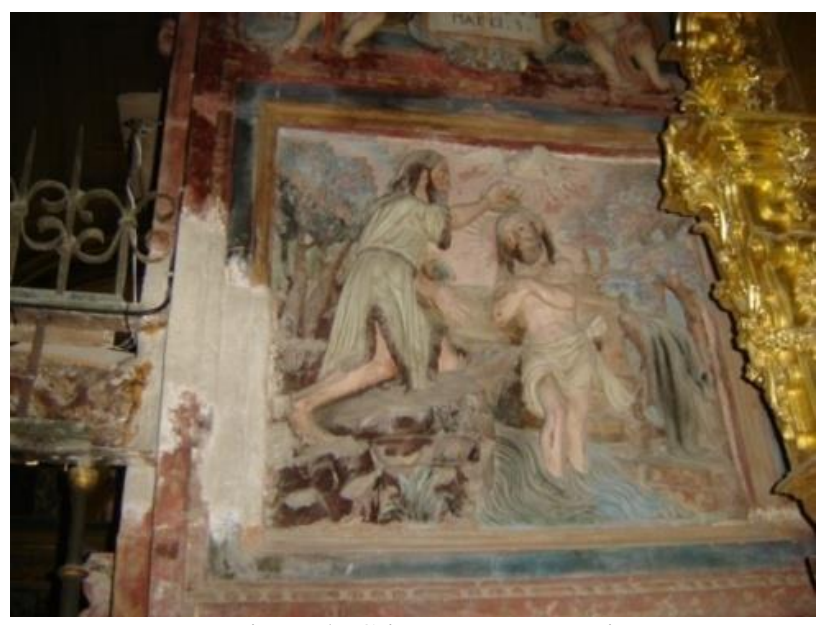

Bautismo de Cristo. Imagen propia.

Respecto a las heráldicas que rematan la capilla en los laterales no vamos a entrar en ellas, pues en una clara brisura de borlas en sable común a los arcedianos ${ }^{61}$ y con el campo personal correspondiente a cada uno de ellos.

Una vez estudiado el interior de la capilla, vamos a fijarnos brevemente en el exterior, por el desarrollo complementario que aquí se hace en torno al mismo tema. En primer lugar, en la base de las pilastras tenemos dos cartelas con alusiones a la muerte (llamativa vanitas que se convertirán en obras comunes en el Barroco y estudiadas en profundidad por el profesor Valdivieso), ${ }^{62}$ como indican las calaveras aladas que rematan las mismas. Una expresa: SPERATIVS TVS / IN MORTE SVA / Prov. 14 (ten esperanza en su muerte). Mientras que en la otra se puede leer: MELIOR EST DIES MORTE / ECCLES 7 (el día de la muerte es inesperado).

Seguidamente existen otros dos tondos, donde se especifica la advocación de la capilla: SAN en uno y MICHAEL en el otro. Sobre ellos, dos hornacinas en las cuales están colocados los pilares de la Iglesia. San Pedro, concretamente, a la izquierda, no se conserva. No ocurre lo mismo con San Pablo, ubicado en la derecha con su iconografía tradicional (espada de su martirio, barba larga y manto rojo). Es una imagen que muestra una clásica torsión, al cruzar el brazo derecho por delante del pecho, para sostener la empuñadura de la espada que clava en el suelo, dejando caer la mano de una manera muy relajada, como si en realidad estuviera posando para el espectador. Existen zonas con un grado ínfimo de realismo, como puede ser el caso de los pies. En realidad, no es una imagen de bulto redondo, sino un relieve plano por detrás, pensado para ser insertado en la hornacina; quizá por esta razón no se conserva el de San Pedro.

Otros dos santos se distribuyen en hornacinas superiores, tras la cartela, que en esta ocasión los identifica: en primer lugar al de abajo y en la segunda línea al superior. Son sostenidas por dos bustos famélicos, que con los brazos abiertos levantan la cartela por encima de su cabeza. En la izquierda la cartela anuncia: S.

\footnotetext{
${ }^{61}$ Woorward, J. 1894. A treatise on ecclesiastical heraldry: 54-56. Edimburgo: W. and A.K. Johston. ${ }^{62}$ Cfr. Valdivieso González, E. 2002. Vanidades y desengaños en la pintura española del Siglo de Oro. Madrid: Fundación de apoyo a la Historia del Arte Hispánico.
} 
PETRVS / ET IACOBVS. Por tanto, el santo superior es Santiago. Vestido con el típico atuendo de peregrino compostelano, su presencia en el programa es clara por su propio carácter tanto de caballero como de patrón de España.

$\mathrm{Su}$ policromía es curiosa, pues lo normal es que presente la túnica en tonalidades oscuras, en cambio luce palo de rosa con manto blanco (debemos apreciar la riqueza cromática de toda la capilla). Es reconocible perfectamente tanto por sus largas barbas como por el gorro con la concha de vieira. Responde a la típica iconografía española, diferente de su condición de uno de los principales apóstoles, como suele ser presentado en la mayoría de las iglesias de Roma. Aparece en actitud tranquila, con la generalidad que caracteriza a todas las imágenes y con una cierta desproporción en las manos, quedando la derecha (apoyada en el pecho) con unos dedos muy alargados y una muñeca que no se corresponde bien con la forma y extensión del brazo. La otra mano la lleva hacia la fíbula, con la que se sostiene el manto.

En el lado contrario la cartela anuncia: S. PAVLVS / ET FRANCISCVS. La presencia de San Francisco de Asís en este programa también es clara, en los primeros tratados de su hagiografía existe la creencia franciscana de que su humildad le había granjeado el título de Seráfico Padre ${ }^{63}$ (ocupó el puesto de Lucifer y se convierte en psicopompo, según la tradición haber recibido los estigmas de Cristo de manos de San Miguel).

Podríamos pensar en una devoción personal de los arcedianos (posición que no hemos encontrado en los pocos documentos que se conservan) y que de tenerla en cuenta sería una excepción en el discurso iconológico de la capilla; aun así no podemos negar que uno de los patrones se llamaba Francisco, pero deberíamos pensar entonces en una presencia de San Diego o San Lucas por otro lado que no existe. No debemos tratarlo con un carácter excepcional, pues en realidad forma parte exacta de ese discurso.

No es lógico pensar en devociones particulares, sino en el santo ideal elegido. San Francisco es la negación de todos los vicios, así como el portador de todas las virtudes y, en especial, la de la Humildad, que lo identificaba con el mismo San Miguel. Aparece con el hábito franciscano (quizás un poco más oscurecido de lo normal, que se puede confundir con el negro benedictino, en vez de con el marrón franciscano); la cuerda de esparto ceñida deja claro el hábito. El rostro, un poco diferente al común, pues suele ser generalizado, barbado y con pelo, aquí lo encontramos imberbe y con la parte superior del cráneo rasurado. Su actitud es muy interesante, pues mientras que levanta la mano diestra en actitud de saludar y advertir al espectador, en la mano siniestra muestra la llaga de sus estigmas, indicando su alcance al tercer grado de amor, en donde no tiene cabida ninguna clase de vicio.

En las enjutas del arco dos mujeres vestidas de manera muy decorosa, con túnica y manto de cierto grosor a pesar de dejar a la vista parte del hombro interior, sostienen unas cartelas en donde se anuncian a los patrones de la capilla. La de la izquierda especifica: DE LOS / MU MAG / NIFICOS SIR/ DS SEÑO/ RES DON DI/ EGO LUCA / I DÖ FRAN / DE HERRERA. La otra indica su condición: ARCI / DIANOS / I CANO / NIGOS / DE IAE (Jaén).

Respecto a los relieves del ático, toman el tema de la Salvación desde la óptica de Cristo con un gran relieve central, donde se encuentra el entierro de Jesús, como símbolo de la muerte de Dios, para la redención absoluta de los hombres (una sacramentación mediante el Yacente). ${ }^{64}$

\footnotetext{
${ }^{63}$ Nieremberg, J. E. 1686. Obras filosóficas del Padre Juan Eusebio Nieremberg: Tomo III. Fol. 205. Sevilla.

${ }^{64}$ Cfr. Lorite Cruz, P. J. 2012. "La figura de Cristo Yacente: ¿muerte o sacramentación?" Enero de 2012: № 274: 1-11. Vélez-Málaga: IES Juan de la Cierva.
} 
La composición es muy común, quedando Cristo tumbado en el suelo (en primer plano) sobre una sábana, permaneciendo la cabeza reclinada sobre las rodillas de San Juan, mientras que la Virgen María y Santa María Salomé quedan a un lado compartiendo el dolor y con el manto sobre la cabeza, mientras que Santa María Magdalena con el cabello descubierto besa los pies de Cristo (atributo muy común en este grupo de misterio). En segundo plano, existe otro individuo en oración con la cabeza tapada que no sabemos identificar (suponemos que sea Nicodemo o San José de Arimatea).

A los lados, dos hornacinas albergan otras dos santas de difícil identificación, por falta de atributos. Por esta circunstancia tenemos nuestras dudas y no vamos a dar una personalización que pueda ser errónea.

En el frontón de remate la típica figura de Dios Padre, que se asoma a observar de medio cuerpo con sus largas barbas blancas (símbolo de su existencia eterna). De perfil bendice con la mano derecha, mientras que con la izquierda sostiene el globo terráqueo rematado en la cruz. Existen otras dos virtudes recostadas sobre los catetos del frontón: la Fe y la Justicia, con su apariencia normal (el cáliz y la hostia para la primera y la espada para la segunda).

Aunque es muy común la presencia de estas virtudes en la época, sobre todo en programas realizados bajo la dirección de Vandelvira, hemos de afirmar que son coherentes con la lectura, puesto que la $\mathrm{Fe}$ es la principal de las virtudes teologales, sin ella nada sería posible, puesto que es la que da fuerza para conseguir todas las demás, y la Justicia nos presenta cual será el castigo por seguir el camino de los vicios o la recompensa por ir junto a las virtudes.

Por último, haremos alusión a una placa como remate final, en la que se especifica en latín el SOLI DEO HONOOR ET GLORIA (sólo a Dios honor y gloria), famosa máxima muy utilizada en esta época. Por ejemplo, también la encontramos en la reja principal de la sacra capilla del Salvador de Úbeda.

Como resumen final al extenso comentario que hemos realizado de esta interesantísima capilla, queremos aludir a un grabado de Hendrik Goltzius, en el que el grabador holandés de principios del siglo XVII presenta a Cristo como hortelano, arrojando todos estos males desde un canasto como si se tratara de mala hierba (personificados como animales), mientras que San Miguel en un segundo plano encadena al demonio y en un tercer plano otra vez Cristo resucitado bautiza con la sangre de su costado (vendrá el que no bautizará con agua, sino con espíritu). En esta composición podemos hacer una compleja lectura iconológica, similar al programa de la capilla, pese a no ser utilizadas las virtudes.

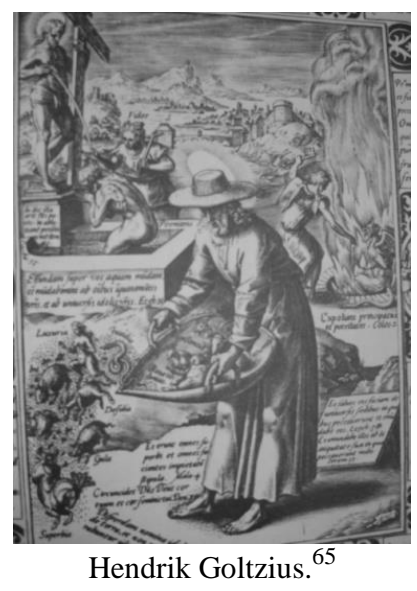

${ }^{65}$ Barscht, A. 1989: tomo 3: 69. 
La capilla ha sido objeto de muchas interpretaciones a lo largo del tiempo. Por ejemplo, en 1955 (momento en el cual la catedral se encontraba en un estado lamentable de abandono) José Santigosa la define como una obra con cierta influencia del Renacimiento italiano, pero llena de la originalidad de Vandelvira, bañando la piedra con la policromía de tonalidades calientes que demostraba su propia sensibilidad artística en aquellas imágenes de sugestivo modelado y correcto dibujo. ${ }^{66}$ Posteriormente han aparecido muchas lecturas, el objeto esencial de este artículo ha sido el de plantear una más, la presencia de los siete archiserafines de manera encriptada que hasta la lectura de nuestra tesis doctoral no se había tenido en cuenta y consideramos que este artículo puede ser base para estudios posteriores no sólo de esta capilla, sino de posibles programas existentes en la península Ibérica e incluso fuera de ella en la que no se haya tenido en cuenta esta lectura.

\section{Bibliografía.}

-AAVV. 2000. Guía de Úbeda y Baeza. Torredonjimeno: Universidad de Jaén.

-AAVV. (reed. 1998). La Sagrada Biblia. Madrid: Ediciones San Pablo.

-AAVV. 1976. Symboles de la Renaissance. París: Presse de l'Ecole Normale Supérieure.

-Aquino, T. de. Escrita en el siglo XIII (reed. 1988). Suma Teológica. Madrid: BAC.

-Alas Clarín, L. (reed. 2005). La Regenta. Madrid: Edimat Libros.

-Aragón Moriana, A. 1991. "Noticias en torno a Bernardo Lorente Germán." Senda de los Huertos. Revista cultural de la provincia de Jaén: 22: 47-50. Jaén: Asociación amigos de San Antón.

-Barschts, A. 1989. The Ilustrated. Nueva York: Abaris Books, Nueva York.

-Blasco de Lanuza, F. de. (O.S.B.). 1652. Patrocinio de Ángeles y combate de demonios... Es una ilustración de los beneficios que hacen los ángeles de la guarda a los hombres. Real Monasterio de San Juan de la Peña.

-Brancasi, C. (O.F.M.). 1646. De angelis. Napoli = Nápoles: Ex Regia Typographia Egydij Longhi.

-Calderón de la Barca, P. (reed. 2007). El gran teatro del mundo. Barcelona: Linkgua Ediciones.

-Cayón, J. 1995. Compendio de las monedas del Imperio Romano. Madrid: Editado por el autor.

-Cuadros Trujillo, F. 2010. "La iconografía en la arquitectura religiosa renacentista: la capilla de San Miguel en la catedral de Baeza." Claustro de las artes: 2010: 80-89. Baeza: Asociación Alcázar Cultural.

-Cuevas Mata, J; Del Arco Moya, Ju. y Del Arco Moya, Jo. (reed. 2001) Relación de los hechos del muy magnífico e más virtuoso señor, el señor Don Miguel Lucas, muy digno Condestable de Castilla. 1564. Jaén: Universidad de Jaén.

-Dante Alighieri. (reed. 1987). La Divina Comedia. Madrid: Editorial Mediterráneo.

-De Santos Otero, A. (colección 2003). Los Evangelios Apócrifos. Madrid: Biblioteca de Autores cristianos.

${ }^{66}$ Santigosa Fuertes, J. 1955. "El altar de San Miguel de la catedral de Baeza.” Paisaje: 1955: 1060-1061. Jaén: Edición facsímil de Riquelme y Vargas. 
-Domínguez Cubero, J. 1989. La rejería de Jaén en el siglo XVI. Jaén: Diputación provincial de Jaén.

-Homero. (reed. 1982). La Odisea. Madrid: Gredos.

-Interián de Ayala, Fr. J. 1782 (reed. 2001). El pintor christiano, y erudito, ó Tratado de los errores que suelen cometerse freqüentemente en pintar, y esculpir las Imágenes Sagradas. Traducido al castellano por Don Luis de Durán y Bastéro. Joaquín Ibarra, Madrid 1782. Alicante: Edición facsímil.

-León Coloma, M. A. 1990. "Un programa iconográfico de vicios y virtudes en la catedral de Baeza." Ephialte. Lecturas de historia del arte: $\mathrm{N}^{\circ}$ 2: 312-315. VitoriaGasteiz: Universidad del País Vasco. Instituto de estudios iconográficos de VitoriaGasteiz.

-Lorite Cruz, P. J. 2011. "El armario de las tres llaves de la catedral de Baeza, un interesante discurso de virtudes del siglo XVI." Claseshistoria: septiembre 2011: 221: 1-16. Vélez-Málaga: IES Juan de la Cierva.

-Lorite Cruz, P. J. 2010."El sepulcro de Pedro Muniz de Molina, deán de la catedral de Lima. Los reyes magos en la catedral de Baeza, un icono procedente de Lima. Nonnullus: 6: 90-95. Badajoz: Plataforma digital Nonnullus.

-Lorite Cruz, P. J. 2010. Iconografía de San Miguel en la diócesis de Baeza-Jaén. Jaén: Tesis doctoral defendida en el departamento de Patrimonio Histórico de la Universidad de Jaén en 2010. Editado el primer tomo en 2012. Säarbrucken: Editorial Académica Española.

-Lorite Cruz, P. J. 2012. "La figura de Cristo Yacente: ¿muerte o sacramentación?" Enero de 2012: Nº 274: 1-11. Vélez-Málaga: IES Juan de la Cierva.

-Lorite Cruz, P. J. 2011. "Las capillas de la catedral de Baeza según la visita realizada en 1625." Claseshistoria: agosto 2011: 216: 1-28. Vélez-Málaga: IES Juan de la Cierva.

-Lorite Cruz, P.J. 2010. "Las iconografías de Santa Ana como precedentes de las Inmaculada Concepción, el beso en la puerta de Jerusalén y la Sagrada Parentela. El triunfo de la mujer en la estirpe de Cristo. II Congreso virtual sobre historia de las mujeres: Comunicación N. ${ }^{\circ}$ 5: 1-13. Jaén: Asociación Amigos del Archivo Histórico Diocesano.

-Mahoma. Escrito en el siglo VII (reed. 2007). El Corán. Madrid: Edimat.

-Nieremberg, J. E. 1686. Obras filosóficas del Padre Juan Eusebio Nieremberg. Sevilla.

-Ratti, A. (Pío XI) 1935. Rituale Romanum:78-79. Ciudad del Vaticano: Editio Juxta Typicam Vaticanam.

-Ripa, C. (reed. 2002). Iconología. Madrid: Ediciones Akal.

-Santigosa Fuertes, J. 1955. "El altar de San Miguel de la catedral de Baeza." Paisaje: 1955: 1060-1061. Jaén: Edición facsímil de Riquelme y Vargas.

-Valdivieso González, E. 2002. Vanidades y desengaños en la pintura española del Siglo de Oro. Madrid: Fundación de apoyo a la Historia del Arte Hispánico.

-Woorward, J. 1894. A treatise on ecclesiastical heraldry. Edimburgo: W. and A.K. Johston.

Recebido para publicação em 15-06-15; aceito em 29-07-15 